\title{
New Master-Planned Cities and Local Land Rights: The Case of Konza Techno City, Kenya
}

\author{
FEMKE VAN NOORLOOS, DIKY AVIANTO and ROMANUS OTIENO OPIYO
}

\begin{abstract}
Consortia of investors, developers and architects, sometimes in collaboration with national governments, have proposed a number of new utopian urban megaprojects or 'new cities' across Africa. While such speculative, planned forms of satellite urbanization increasingly gain attention in urban development debates, empirical evidence on their impacts is lacking, particularly when it comes to access to land and livelihoods of surrounding populations. In this paper we delve into the Kenyan experiences with Konza Techno City, the newly planned city south of Nairobi envisioned to become Africa's main ICT hub or 'Silicon Savannah'. While there is currently little more than a fence that has been put up around the planned city, real life effects are clearly visible. As a buffer zone was established around the project to prevent 'informality', surrounding villages experience insecurity of land tenure and livelihoods. On the other hand, the area has attracted many people seeking opportunities or speculating on future profit. The case illustrates that the mere announcement of a new city can trigger various forms of direct and indirect exclusion. It also shows that the fast-tracking of the project by high government interests can cause problems for community consultation and participation, but also that the state is highly ambivalent, and has little power to prevent delays or control informal development. Rather than being a simple instance of 'land grab', spatial differences and temporal changes make for a constantly shifting landscape of actual and potential impacts. The main problem of new cities lies in the failure to accept 'informal' development as being an intrinsic part of African cities.
\end{abstract}

In search for ways to jump on the 'world city' train, governments across Africa are increasingly lured by the promises of visionary urban megaprojects or 'heterotopias' (Carmody and Owusu, 2016; Côté-Roy and Moser, 2018; van Noorloos and Kloosterboer, 2018; Watson, 2013). In recent years a variety of investors, developers and architects have proposed master-planned new cities for Africa, sometimes in collaboration with national governments: van Noorloos and Kloosterboer (2018) count at least seventy (planned and existing) from 2000 to 2017. Such new property investments in Africa's cities often take the form of entirely new masterplanned cities built up from scratch as selfcontained enclaves, often at the peripheries of existing cities. This new wave of utopian new city plans is still to some extent a drawing board exercise (the majority of the projects have not been constructed - van Noorloos and Kloosterboer, 2018), but although not yet realized, their effects are already being felt.

Urban megaprojects are an important part of current mainstream global urbanism and 
are criticized as 'urban revolutions from above' (Sheppard et al., 2015) that displace the poor in favour of elitist spaces. As part of the increasingly global flows of urban finance, knowledge and ideas, new city master plans are springing up around Africa's cities, which are viewed as a new global frontier of urban investment (Côté-Roy and Moser, 2018; Watson, 2013). For governments and other national and urban stakeholders, the temptations of shiny modern images are difficult to resist in the midst of 'Africa rising' rhetoric (Côté-Roy and Moser, 2018). In their glossing over (or at best ignoring) existing cities, new masterplanned city plans are criticized for envisioning elitist enclaves which do not solve urban problems and may present new risks. They can create socio-spatial segregation through walling and gating, and by providing housing that is inaccessible for the large majority of the urban poor. Furthermore, they enhance fragmentation of urban governance through privatization of service delivery in these enclaves (Cirolia, 2014; Grant, 2015; Murray, 2015; van Noorloos and Kloosterboer, 2018; Watson, 2013).

The literature on new cities in Africa has taken a variety of directions in recent years, but recurring themes are the cities' policy framings, planning models, and (to a lesser extent) financial flows (Carmody and Owusu, 2016; Cirolia, 2014; Côté-Roy and Moser, 2018; Fält, this issue; Grant, 2015; van Noorloos and Kloosterboer, 2018; Watson, 2013). One issue that is often overlooked, also by planners and policy-makers, concerns the consequences of these projects for pre-existing and surrounding populations and their livelihoods and access to resources (van Noorloos and Kloosterboer, 2018). Today's African utopian new city plans provide particularly salient examples of the large-scale speculative urban land investments that have been discussed under the concept of 'urban land grabs' (Klaufus et al., 2017; Steel et al., 2017; van Noorloos et al., 2018). Given the large scale of the projected urban visions, dramatic changes in land access and use can be expected. Such changes are particularly problematic as many projects take place in hybrid peri-urban or 'rurban' spaces, which are already highly complex in terms of land governance. Against the background of increasing land scarcity and global struggles over land rights, Africa's new cities raise concern, particularly given their large scale and enclave character. Analysing Africa's new cities through the concept of urban land grab allows us to delve more deeply into the local effects and actual implications on the ground, in their full complexity.

While new cities increasingly gain attention in urban development debates, empirical evidence on their implications is lacking. What happens to surrounding people's access and rights to resources, particularly land? Who benefits or loses? While many of these new cities are still on the drawing board and may not get beyond that, the planning and early construction phases of some of the projects can give us insights into the possible impacts. In this paper we draw from the Kenyan experiences with Konza Techno City, the newly planned city south of Nairobi envisioned to become Africa's main ICT hub or 'Silicon Savannah'.

This article is based on a three month field research conducted in Nairobi, Machakos and Makueni Counties on the proposed Konza City, in February to May 2017 (Avianto, 2017). Questionnaire surveys were conducted with inhabitants of Old Konza (28) and Malili (35) who were selected randomly - the survey was meant to collect basic demographic and livelihood characteristics, and a few opinions on the project and process. Semi-structured interviews (8) were conducted with government officials, urban planning experts, and local leaders, and informal conversations, field observations, and transect walks with inhabitants of the two villages complemented the data collection. In addition, the planning process was documented by means of planning documents, expert interviews and secondary literature. In this way we combined qualitative data analysis on the planning process, livelihood changes, and perceptions on impact with descriptive statistics of live- 
lihoods, perceptions and participation/ consultation, to provide an exploratory yet holistic picture.

In this article, after presenting a literature review on new cities and urban land grabs and presenting the conceptual framework that underlies the research, we present a brief description of the Konza Techno City project and its surrounding area and population. Then we briefly present the situation in terms of land tenure and access to land in the project and the surrounding buffer zone. After that we provide an analysis of the project's impacts with regards to access to land, which evolves along two lines (partly along the framework of 'urban land grabs' developed by Van Noorloos et al., 2018): (1) indirect displacement chains through land tenure insecurity and speculative development in the buffer zone, and (2) the ambivalence of actors related to the project. We conclude that Konza cannot be analysed as a simple case of 'land grab': spatial differences and temporal changes make for a constantly shifting landscape of actual and potential impacts. New cities' failure to work with urban informality is a key problem that extends also to their dealings with surrounding communities.

\section{Literature Review and Conceptual Framework: New Cities as Urban Land Grabs?}

Urban megaprojects are an important part of current mainstream global urbanism, and criticized as 'urban revolutions from above' (Sheppard et al., 2015) that displace the poor in favour of elitist spaces. Within the neoliberal trend of intensified inter-city comparison and competition, city governments work hard to acquire an image as 'world cities', which tends to result in the replication of existing urban models in top-down ways in new places (Bunnell, 2015; Carmody and Owusu, 2016; Côté-Roy and Moser, 2018; McCann; 2011, 2013; McCann and Ward, 2012; Roy and Ong, 2011). In that context African cities are represented as a new global frontier of urban investment (Côté-Roy and Moser, 2018; Watson, 2013; Sheppard et al., 2015).

The master-planned new city is one of the global urban models that is driven into African cities through the actions of global consultancies, architects and planners, financial institutions and the like (Côté-Roy and Moser, 2018; Carmody and Owusu, 2016). New master-planned cities have a longer history in Africa, linked to post-independence new capital cities such as Abuja (Keeton and Provoost, forthcoming), but most of the current plans are different particularly in their dependence on private sector finance and planning. Many of these utopian visions are today planned as public-private partnerships, but governments are often relegated to providing cheap land and putting in place regulations. For them, the temptations of shiny modern images are difficult to resist in the midst of 'Africa rising' rhetoric (Côté-Roy and Moser, 2018). The building of symbolic power through hypermodern 'world cities' in order to attract attention - hence investment in the global economy is an important reason for local and national governments to become involved in such projects (Goldman, 2011; Steel et al., 2017). In their glossing over (or at best ignoring) existing cities in favour of global connections (Carmody and Owusu, 2016), new master-planned cities' plans are criticized for envisioning elitist enclaves which do not solve but potentially worsen urban problems (van Noorloos and Kloosterboer, 2018). They risk socio-spatial segregation through walling and gating and by providing housing that is inaccessible to the large majority of the urban poor. Furthermore, they enhance fragmentation of urban governance through privatization of service delivery (Cirolia, 2014; Grant, 2015; Murray, 2015; van Noorloos and Kloosterboer, 2018; Watson, 2013). The new city developments on the African continent so far seem highly speculative and consumptive ('bubble urbanism': Steel et al., 2017), rather than enhancing the necessary productive economic development such as new industries: 
Current urban investments build on existing weaknesses rather than transforming them; they offer mostly opportunities for speculation and quick profit to be made from residential and commercial development, thereby reinforcing the externally dependent character of urbanisation. (van Noorloos and Kloosterboer, 2018, p. 1237)

Nevertheless, some caution is needed in assessing the actual consequences of new cities: as already mentioned most are only in the planning phase and some may not get beyond that. Also, inevitably there will be differentiation between new cities. Even though most new cities are developed as privatized enclaves and therefore exclusionary by design, experiments in 'inclusive design' are emerging for some cities (Keeton and Provoost, forthcoming). Inclusive and sustainable 'mixed city' planning is sometimes mentioned as a specific aim, but as the case of Appolonia City (Ghana) shows, multiple rationalities can easily overrule such ambitions in reality (Fält, this issue). Furthermore, government-planned new satellite cities are also re-emerging, often meant as a way for authoritarian states to provide housing for the poor and middle classes, but also to assert political authority (Croese and Pitcher, 2019; Planel and Bridonneau, 2017). The effects of new cities are thus diverse and can only be assessed in the long term. At the same time, urban megaprojects and master visions do create certain types of impact from their first planning phase onwards (De Boeck, 2011; Smith, 2017). One type of effect that is already observable, even if the cities have not been built, concerns access to land and the livelihoods of surrounding populations.

Large-scale urban projects can create severe land conflict and displacement, as their surrounding spaces are hardly ever 'empty' (Leitner and Sheppard, 2018). While largescale slum demolition within cities is widely reported, the less well known instances of large-scale land development in the periurban interfaces around African cities are also problematic. These suburban and peri-urban areas are exactly the places where most new city projects - the satellite cities - are planned.
In these spaces in between the rural and the urban, the complexity of land governance arrangements, with many intersecting land claims and types of tenure/governance, often leaves the poor without much protection in the face of land development (van Noorloos and Kloosterboer, 2018).

Such concerns are the subject of a widening body of literature on global 'land grabs' or large-scale land investments in the Global South. While this debate used to be predominantly rural, recently researchers have argued for a more integrated view of the rural and the urban in land investments (see the introduction to this special issue). ${ }^{1}$ For example, the transformations engendered by urban land investments are not limited to the urban: often they profoundly transform the rural surroundings of cities (Zoomers et al., 2017). Indeed, the impacts of Africa's new cities reach well beyond the city and, given their location in the peri-urban areas, their potential displacement and livelihood impacts (due to pressure on resources and the commons) bear much resemblance to typical 'rural' land grab cases. By using the concept of 'urban land grabs', researchers attempt to make sense of the increasing scarcity of land and pressures on land worldwide, and the specific configurations of these developments in the urban sphere (Steel et al., 2017 and Introduction to this issue).

The notion of urban land grabs can advance research on new cities in various ways. The literature on new cities thus far has focused on the policy framings, planning models and visual spectacles of the 'fantasies' and, to a lesser extent, on the financial flows (Carmody and Owusu, 2016; Cirolia, 2014; Côté-Roy and Moser, 2018; Fält, this issue; Grant, 2015; van Noorloos and Kloosterboer, 2018; Watson, 2013). While such issues are key and logical as many of these projects are still in a starting phase, research is inevitably often scaled at the national or global levels: what happens at the local level is often unclear. By framing the phenomenon of new cities in land grab terms we delve more deeply into the local effects 
and look at displacements, consultations and livelihood changes which result from these new planning models, policies and financial flows.

In furthering the urban land grab debates, Van Noorloos et al. (2018) have proposed three new directions: (1) focusing on the sequential chain of effects of displacement; (2) paying more attention to the ambivalent roles and contradictory interests of different actors; and (3) taking the three-dimensional aspects of land development into account. In this article we take this framework as a starting point and aim to further the first two of these lines with the case study of Konza Techno City in Kenya. ${ }^{2}$

First, focusing on the sequential chains of displacement means that displacement should not be regarded as a one-off process, but rather as a long-term development which may include various steps and contradictory developments. Not only direct outright dispossession should be problematized (e.g. Gillespie, 2016), but also indirect types of displacement that often occur over longer periods of time, such as different types of gentrification, and enclosure of the commons (van Noorloos et al., 2018). In the conversion of peri-urban spaces to new urban projects, such indirect displacement chains often occur through the mechanisms of excluding pastoralists and other temporary or mobile populations from access to land and other natural resources that were previously available for use. Dell'Angelo et al. (2017) coin this phenomenon 'commons grabbing'. Similar exclusions occur when new land is reclaimed from the sea, impacting fishermen's livelihoods (van Noorloos et al., 2018). The all-encompassing character of new cities may also reinforce the tendency to formalize and 'modernize' the informal (e.g. 'clean the city' of street vendors, street hawkers, etc.), thereby intensifying exclusionary mechanisms. In addition, those types of displacement where people wholly or partly consent to their relocation (voluntary displacement) also need to be taken seriously: the voluntary versus involuntary dualism is often blurred, particularly in current rural-urban land grabs where people's urban aspirations are heightened (ibid.) Hence multiple types of accumulation, contestation and displacement can be involved (Leitner and Sheppard, 2018).

The second argument states that a deeper investigation into the actors involved in urban land grabs, and their changing roles and contradictory interests, is needed. While 'land grab' and 'development' are often presented as a dichotomy with rural cases frequently presented as land grabs and urban cases as development, the urban cases of land acquisitions show us that it is not so easy to draw the line or assign clear 'culprits' for land-related exclusions and displacements, due to the complex multitude of hardly traceable actors involved (van Noorloos et al., 2018). The role of the state, for instance, is often ambivalent: in African new cities we see the role of the state varying from being a mere land broker to an outright urban developer (Cain, 2014; Murray, 2015; van Noorloos et al., 2018; Watson, 2013), although the broker role seems more common. The variety of scales and state institutions involved in any development project also urges us to see the state as consisting of multiple, contradictory actors and interests. Often the state is also unable to steer process outcomes in these complex projects (van Noorloos et al., 2018). One example of this inability is the stalling of many new city projects such as Wescape and Modderfontein (South Africa) and Hope City (Ghana) (see for an overview Van Noorloos and Kloosterboer, 2018). In addition, we can mention the frequent emergence of widespread 'informal' development around the new cities, as in the older 'new city' of Brasilia (Scott, 1998). New migrants flock to the surroundings of planned new cities in anticipation of economic opportunities and speculative developments, which also shows that the ideal of a unified 'local community' is very problematic. Analysing the multitude and ambivalence of actors around urban land deals is important as these complicate the question of who is responsible for important issues such 
as consultation and resettlement, and thus who people can turn to for fulfilling their rights.

\section{Konza Techno City:}

\section{The Project and Its Surroundings}

Konza Techno City is an ambitious new city plan in Kenya. The project is managed by a Development Authority, a semi-governmental institution or special purpose entity working under (and reporting to) the Kenyan Ministry of Information and Communications (MIC), which develops partnerships with a number of (mostly international) private developers (Konza Technopolis, 2015). ${ }^{3}$ The US-based consultancy Tetra Tech leads the master planning. A number of other consultancy companies have also been important in advancing the project, such as the World Bank's International Finance Corporation (acting as a lead advisor on project structuring and bid out) and McKinsey (IFC, 2014; Smith, 2017). While the first idea for the city emerged in 2006 at the MIC, from 2008 onwards the planning process started. After multiple changes in project size and location, in 2010-2011 the land in the current location was bought. This greenfield site far away from existing infrastructures was chosen for a much more ambitious plan (interview, former MIC policymaker). More state investment was thus needed before any private investment could be attracted, therefore in 2012 the Konza Technopolis Development Authority (KoTDA) was established (IFC, 2014; interview, former MIC policy-maker). In 2013, former President Mwai Kibaki broke ground in Malili to mark the start of the project. Indeed, the project was planned at the national level, primarily by the MIC (which is the only state institute represented in the KoTDA), but with high national symbolic power and presidential backing (see also Splinter, 2014).

This national government interest is also

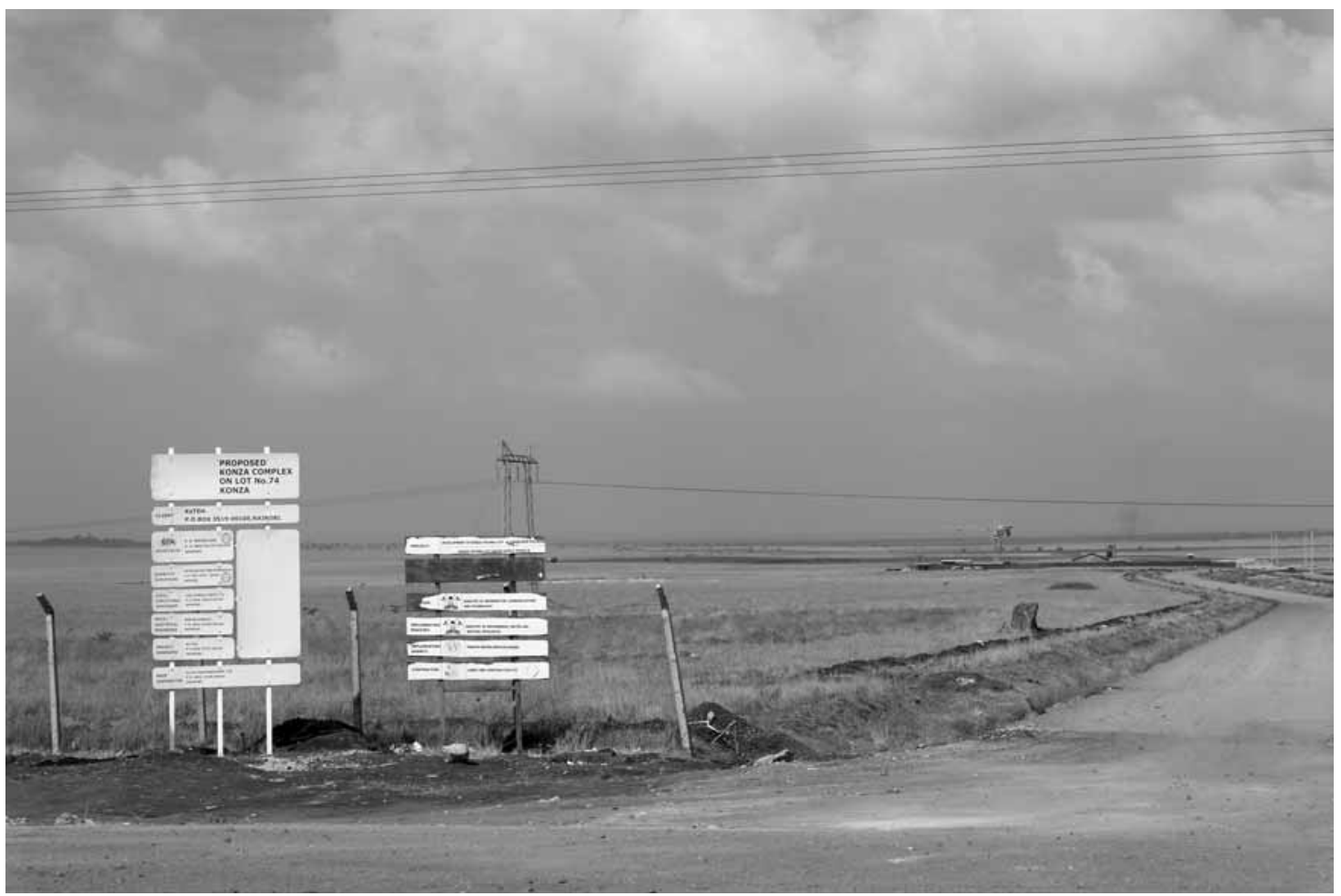

Figure 1. Main entrance to the Konza Techno City project. (Source: Avianto, 2017) 
clear from the fact that Konza Techno City has been an iconic part of the Kenya Vision 2030 national development strategy, which aims to further the country's economy to reach a middle-income status, based on the service sector, particularly Information and Communication Technology (ICT) (Government of Kenya, 2007; interview with MIC). Within this vision, the strategy for Nairobi 'Nairobi Metro 2030' aims to reinvent the city as a 'world class African metropolis' and 'an iconic and globally attractive city' (Smith, 2017). As part of this strategy Konza Techno City was envisioned as a flagship project that would become the 'Silicon Valley of Kenya' (or 'Silicon Savannah'): a major ICT hub meant to 'spearhead technological innovation and development' at the national level, by attracting 'high-tech industries, start-ups, and universities' and by providing national and global connectivity (Konza Technopolis in Klaufus et al., 2017). Konza Techno City, which is planned about $60 \mathrm{~km}$ south of Nairobi as a satellite city, is holistic and multifunctionally planned, combining housing, offices/work, a university, a hospital, schools, hotels, shopping, etc. The Ministry of Information and Communications through KoTDA leases the land $(5,000$ ha in total) to private developers for 99 years and provides public infrastructure and regulatory guidelines. The project would create 17,000 jobs and attract 200,000 residents.

Despite government's high ambitions, Konza Techno City has been suffering from delay and intra-governmental conflict. While the government was responsible for developing basic infrastructure (IFC, 2014), due to funding difficulties it was three years before the first infrastructure provision began, and today there is hardly any construction (apart from slight progress on roads, water boreholes and electricity infrastructure - Government of Kenya, 2018). The major part of the area to be developed is currently just grassland with a fence. With multiple delays it is increasingly uncertain whether the city will ever be created as envisaged (The Star, 2018).
Intra-governmental problems were blamed: KoTDA lacked the capacity to oversee urban planning and adequately deal with the complex institutional and legal framework (Splinter, 2014; Konza Technopolis, 2015), but it also was not autonomous enough to claim its own assigned budget from government and exert power to get things started (Konza Technopolis, 2015; The Star, 2018). The global financial crisis probably also played an important role (Smith, 2017) in stalling investment. It is not entirely clear how the newly installed government (2017) intends to further the project.

The Konza Techno City site (5,00o ha), including its planned buffer zone (20,000 ha), falls within three counties: Machakos, Makueni, and Kajiado. The area is part of the arid and semi-arid lands (ASALs), where pastoralism is historically an important source of livelihood. The buffer zone was established to prevent 'uncontrolled' informal developments from popping up around the project, as these could become an 'eyesore' and discourage investors (interview, urban planning expert; Wapenaar, 2015). The project area itself is currently not used or inhabited, but there are two main communities in the buffer zone area: Old Konza and Malili (figures 2 and 3). Both are very different in their land use, livelihoods and histories. Table 1 shows the basic characteristics of our survey sample in both villages $(\mathrm{N}=63)$.

The community of Malili or Malili Centre used to be part of the Malili Group Ranch which took up much of the current Konza Techno City area (this will be explained below). The group ranch members allocated land for a small commercial centre near the Nairobi-Mombasa highway, which is now Malili Centre (Mulinge, 2014). Around 2010 and 2011 the town experienced slow growth: some fixed structures were set up, such as shops and hotels. As transect walks and informal conversations with residents show, after the announcement of Konza Techno City in 2012, growth started to take off more rapidly, and a lot of land was further sub- 
divided and sold. One respondent who had lived in Malili for to years explained: 'It was nothing here 10-12 years ago. It was only empty land and then people started coming here for searching new business opportunity'. The announcement of Konza Techno City and the associated expectations also attracted large numbers of newcomers from all over Kenya in search of job opportunities, and with hopes for better infrastructure and increasing land prices. Urbanization intensified and more and more semi-permanent structures were constructed (transect walks and informal conversations Malili). The current population is estimated at 1,500-2,000. Malili's population today consists mostly of recent migrants who arrived less than 2 years ago (40 per cent table 1). Most rent their house (77 per cent - table 1), while most of the original shareholders of the group ranch live elsewhere (interview, member of the County Assembly of Makueni). Malili Centre has grown into a residential and commercial town, with services such as shops, kiosks, hardware, food joints,

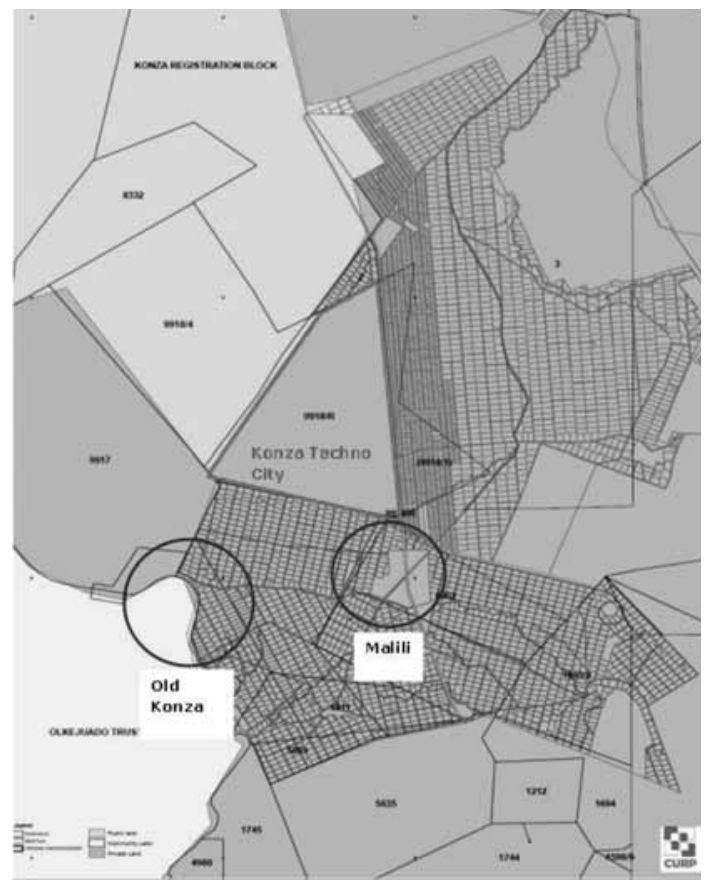

Figure 2. Land tenure around Konza Techno City. (Source: Avianto, 2017, modified from Ministry of Lands map)

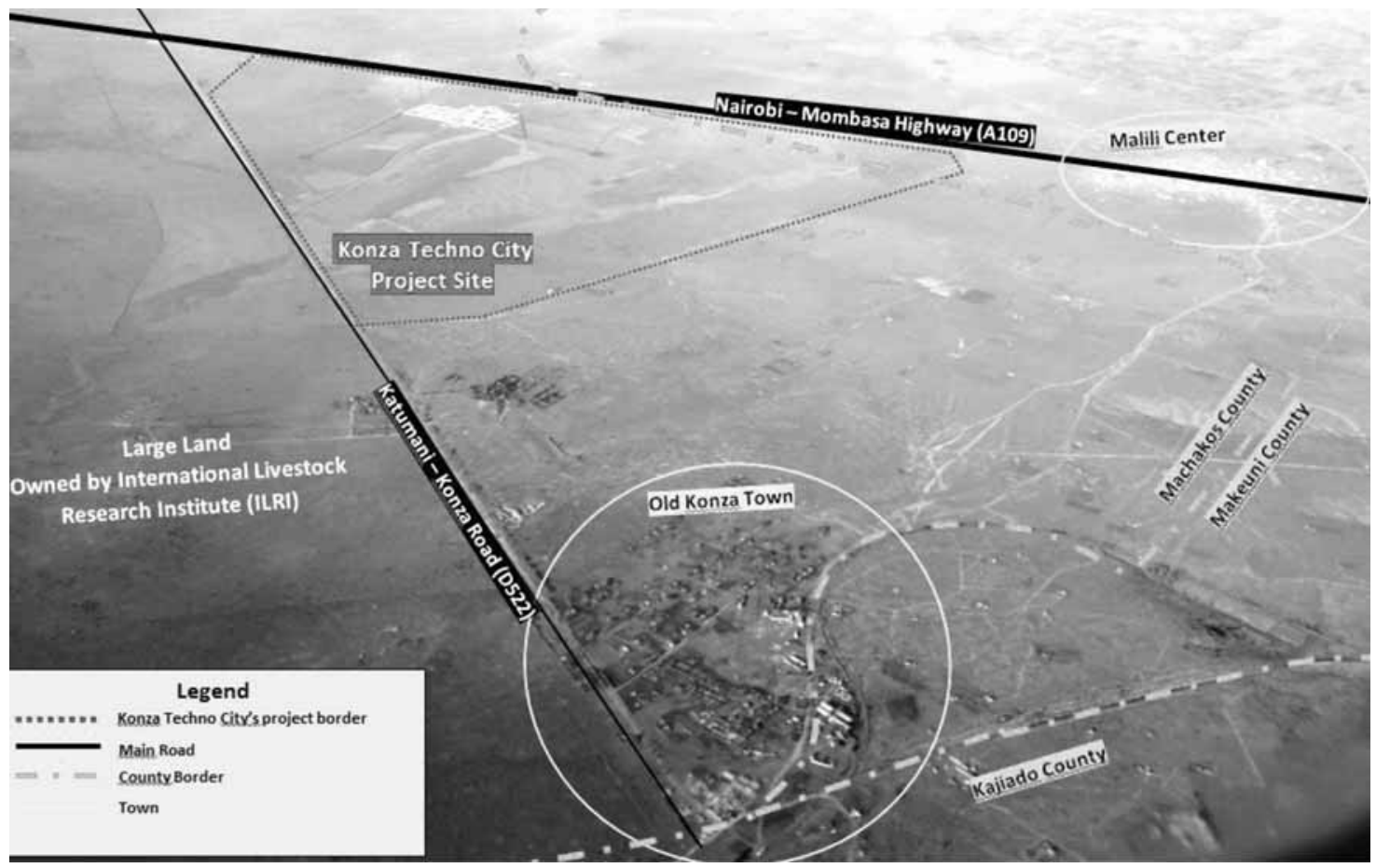

Figure 3. Aerial view of Konza Techno City and its surroundings. (Source: Avianto, 2017) 
Table 1. Main characteristics of survey sample (Source: authors' survey, $\mathrm{N}=63$ )

\begin{tabular}{|c|c|c|}
\hline Characteristic/question & Old Konza & Malili \\
\hline $\begin{array}{l}\text { Gender } \\
\text { Age }\end{array}$ & $\begin{array}{l}7 \text { females, } 21 \text { males } \\
\text { 18-34: } 18 \\
\text { 35-51: } 4 \\
\text { 52+: } 5 \\
\text { Missing: } 1\end{array}$ & $\begin{array}{l}13 \text { females, } 22 \text { males } \\
\text { 18-34: } 17 \\
\text { 35-51: } 14 \\
\text { 52+: } 0 \\
\text { Missing: } 4\end{array}$ \\
\hline Number of years living in area & $\begin{array}{l}0-2 \text { years: } 5 \\
3-10 \text { years: } 5 \\
\text { 11-20 years: } 5 \\
21+\text { years: } 13\end{array}$ & $\begin{array}{l}0-2 \text { years: } 14 \\
\text { 3-10 years: } 19 \\
\text { 11-20 years: } 1 \\
21+\text { years: } 1\end{array}$ \\
\hline Main industry of employment & $\begin{array}{l}\text { Farming/pastoralism: } 9 \\
\text { Construction: } 5 \\
\text { Trade and services: } 6 \\
\text { Casual work: } 4 \\
\text { Unemployed/other: } 4 \\
\text { (majority of respondents farm, } \\
\text { some as a secondary activity) }\end{array}$ & $\begin{array}{l}\text { Farming / pastoralism: } 5 \\
\text { Construction: } 5 \\
\text { Trade and services: } 20 \\
\text { Casual work: } 2 \\
\text { Unemployed/other: } 3\end{array}$ \\
\hline Ethnic group & $\begin{array}{l}\text { Kamba: } 15 \\
\text { Kikuyu: } 2 \\
\text { Maasai: } 9 \\
\text { Other: } 2\end{array}$ & $\begin{array}{l}\text { Kamba: } 21 \\
\text { Kikuyu: } 4 \\
\text { Maasai: } 1 \\
\text { Other: } 5 \\
\text { Missing: } 4\end{array}$ \\
\hline Ownership of house & $\begin{array}{l}\text { Rent: } 10 \\
\text { Own: } 18 \\
\text { Squatting: } 0\end{array}$ & $\begin{array}{l}\text { Rent: } 27 \\
\text { Own: } 6 \\
\text { Squatting: } 2\end{array}$ \\
\hline $\begin{array}{l}\text { Opinion on whether government } \\
\text { should control land use in buffer } \\
\text { zone }\end{array}$ & 16 agree, 47 disagree & \\
\hline
\end{tabular}

water selling points, salons, small guest houses and road side selling. People's livelihoods revolve around commercial activities, services and trading (table 1 ).

Old Konza is a small town to the south of Konza Techno City site, with a population between 1,000 and 2,000. In the 1970 the first settlers came to this empty land and started farming and growing livestock in a collective manner, though not under the formal group ranch policy (interviews Old Konza). Most people in Old Konza are long-term inhabitants, 64 per cent having lived there for more than 10 years; most own their house (also 64 per cent - table 1) and have built permanent structures. The rapid developments of Malili have not arrived in Old Konza yet, as it is more distant from the highway. Most people are farmers on their own lands and/or are pastoralists, although often combined with other sources of livelihood (table 1). Old Konza provides for commercial activities such as shops, food joints, and salons, through a small market.

\section{Land Access and Land Tenure in and around Konza Techno City}

Access to land and land tenure in the area is more complex than it initially seems. The government bought the Konza Techno City project land in 2010-2011. It was previously part of the Malili Group Ranch which had already been subdivided in 2005-2006 among its more than 2,000 shareholders (interviews inhabitants; Johari, 2015). Group ranches were 


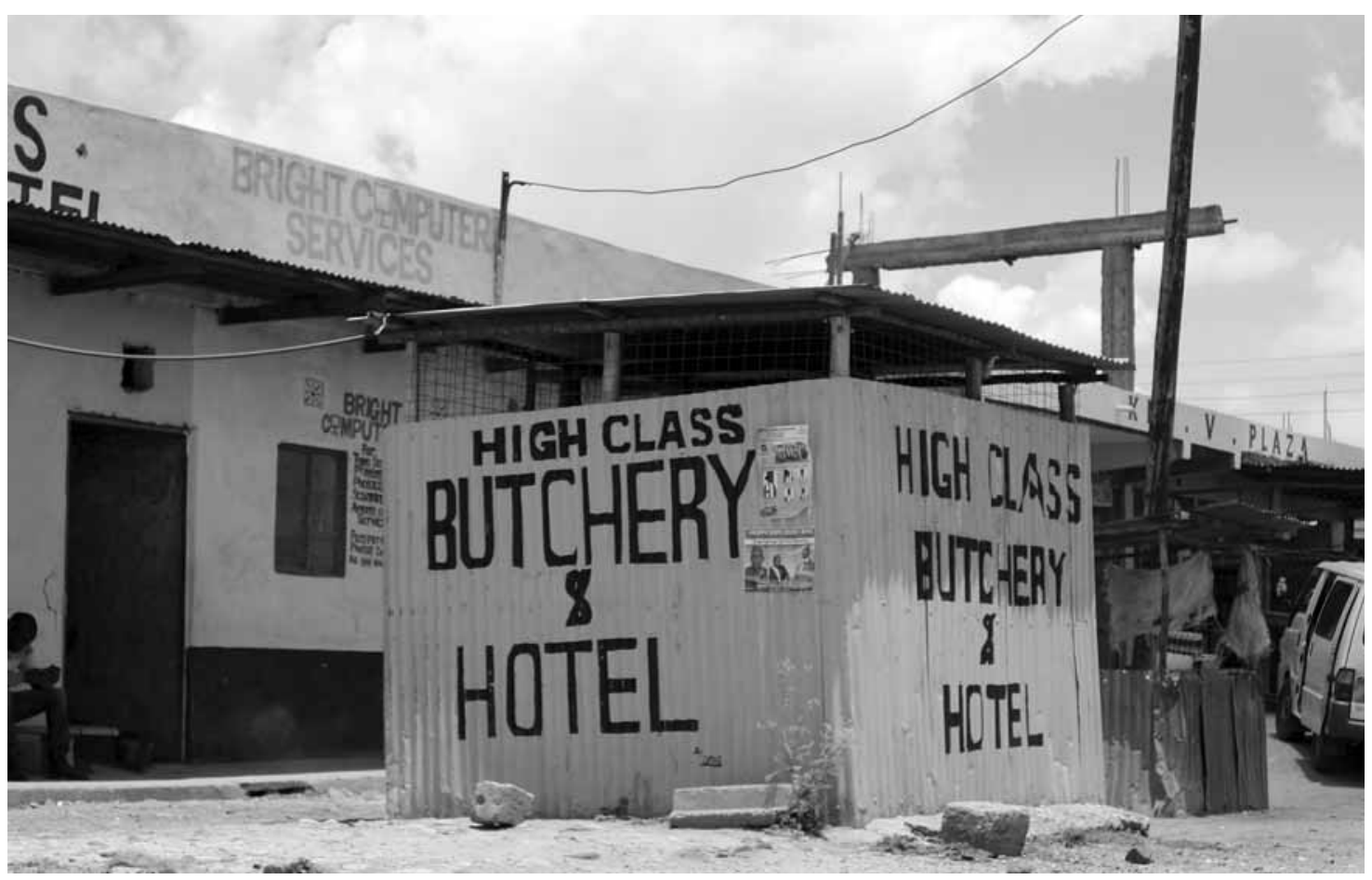

Figure 4. Market area in Old Konza. (Photo: D. Avianto)

set up by law in large parts of Kenya after independence up until the 1980s, in order to increase productivity of the arid and semiarid lands (ASALs). ${ }^{4}$ In the case of the Malili, land formerly occupied by white settlers was bought up as a group ranch by a large group of shareholders (interviews with inhabitants; Johari, 2015). For various reasons many of the group ranches started to subdivide and individualize land not long after establishment (Mwangi, 2007), in the case of the Malili group ranch particularly because of internal mismanagement and conflict which decreased profitability (Johari, 2015). After subdivision it was often difficult to maintain livelihoods on small pieces of land (e.g. 7.8 ha in the case of Malili) and many people started to sell their land. For Konza Techno City, the government negotiated with the directors of this group ranch and reached an agreement for purchase. However, shareholders who had lost their plots claim the amount they received was too little (interview, member of the County Assembly of Makueni; Johari, 2015). Hence the process has involved some conflict and fraud, including a court case.

The project's 20,000 ha buffer zone is the major cause of contention around land use and access nowadays. We briefly outline the basics of land tenure in Old Konza and Malili villages, to provide the background for the analysis. As a privatized and individualized part of the group ranch, initially Malili inhabitants mostly had individual private ownership over their subdivided land plots (DPP, 2013). However, this changed somewhat over time. Malili's rapid development in recent years took place in the absence of planning and infrastructure provision. Hence, further land subdivisions were not formalized: land administration was overruled by the speed of developments (Mulinge, 2014; Mwau, 2013). As a result, an informal land buying and house rental market emerged, along with semi-permanent houses and buildings. When Old Konza was established by settlers in the 
1970s, the land was owned by the government and people were considered squatters, although they were tolerated (interviews inhabitants). In the 1990s the government started giving out allotment letters of the land to each household individually. These letters do not entail much more than a promise and hence fail to provide strong land tenure security, which is why people are still struggling to receive stronger types of ownership (interviews inhabitants).

\section{Buffer Zone, Repulsion and Attraction: Displacement Chains}

As proposed in the concept of indirect displacement, we cannot evaluate displacement effects by looking only at direct project land, or only at instances of actual land lease or acquisition. The experiences around Konza Techno City show that the creation of extra infrastructure and buffer zones can fuel displacements, and new land-use and zoning regulations can create livelihood insecurity.

With the aim of keeping out informal development from springing up around the project, a buffer zone was established around the project. The investors or land owners are required to adhere strictly to a comprehensive Local Physical Development Plan (LPDP), which sets guidelines and standards on how the roads, sewerage, and other infrastructure within the buffer zone should be constructed (DPP, 2013). Old Konza was assigned as a zone of 'modern agriculture' and Malili as a commercial zone. The plan proposes that Malili will be further subdivided to create a sub-zone for residential development, mainly low- and medium-density (Mulinge, 2014). Any construction needs to be approved by KoTDA. At this point, any further construction or subdivision of land is frozen (Konza Technopolis, 2017).

Table 1 shows that approximately three-

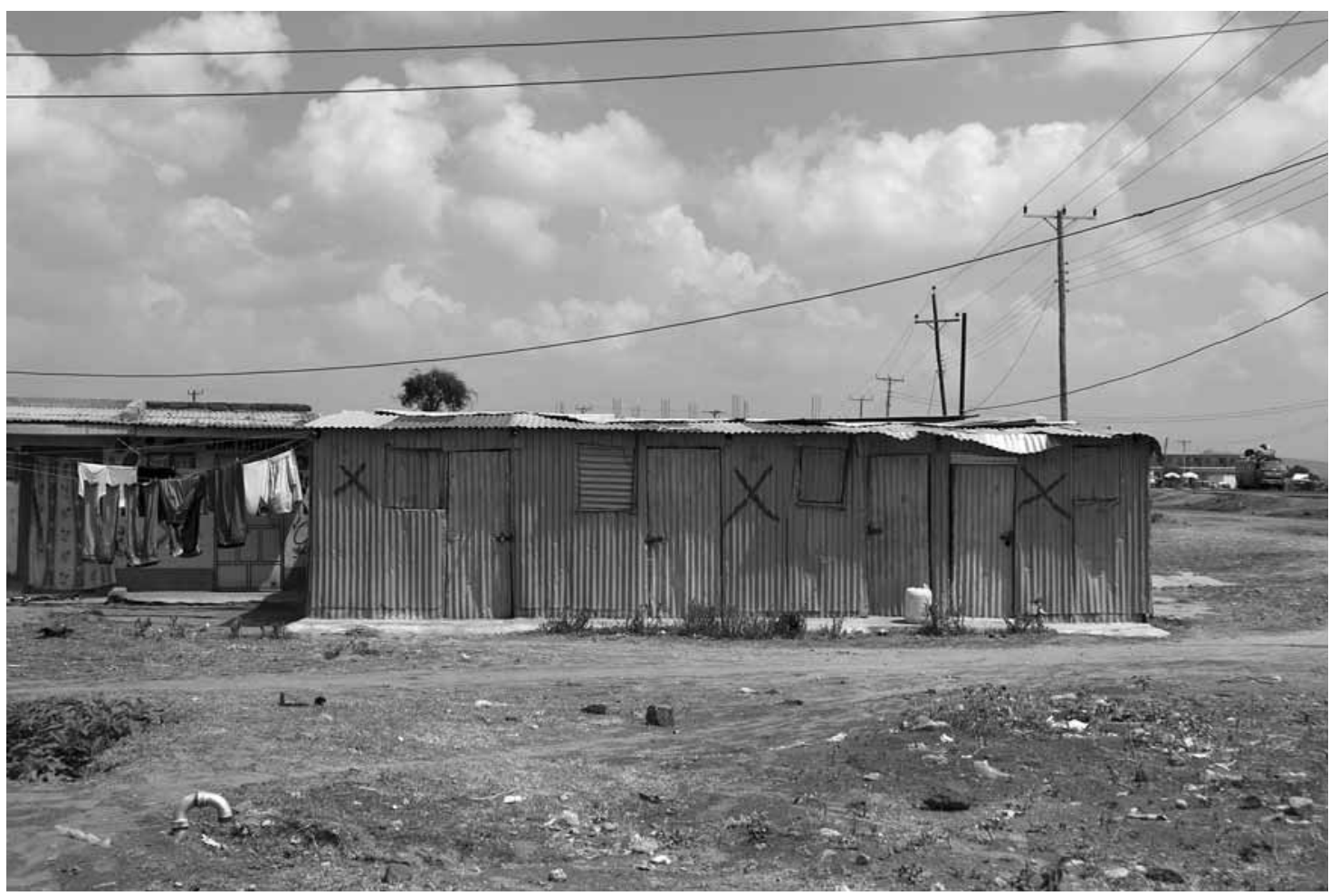

Figure 5. Informal settlement buildings in Malili marked for demolition. (Photo: D. Avianto) 
quarters of survey respondents are against the government land-use regulations from the LPDP. In interviews, residents explained that they are afraid they will be unable to live up to high 'modern' building standards and hence risked demolishing of their house, or being bought out by high-income earners and well-off investors who can meet the required development standards. Indeed, some informal structures in Malili have been assigned as 'to be demolished' (see figure 5) but given project delays no further action has been taken (interview, urban planning expert). In the meantime, interview respondents indicated being more cautious about putting up permanent structures, hence many of the new structures in Malili remain semi-permanent. Old Konza inhabitants were also afraid that the land-use planning would affect their already rather insecure land rights or outlaw their livelihoods.

In addition, in assessing the impacts of large-scale urban plans on land-use and re- source rights, a limited focus on direct displacement or expulsion of sitting land users tends to overlook important land users and livelihoods dependent on the spaces in other ways. Particular groups which are often overlooked are mobile and temporarily inhabiting groups such as (peri-)urban farmers (De Boeck, 2011; Zoomers et al., 2017; Shannon, in this issue), fishers and pastoralists. Old Konza consists of long-term (partly Maasai) inhabitants with, to some extent, pastoralist and agriculturebased livelihoods (see table 1 ). The fence constructed around the Konza Techno City project site established a barrier which prevented local pastoralists from grazing their herds of cattle in the area, which they had traditionally used for that purpose (interview, chief Old Konza) (figure 6). Currently pastoralists are seen grazing cattle near the NairobiMombasa highway, which poses road safety problems.

On the other hand, while some groups

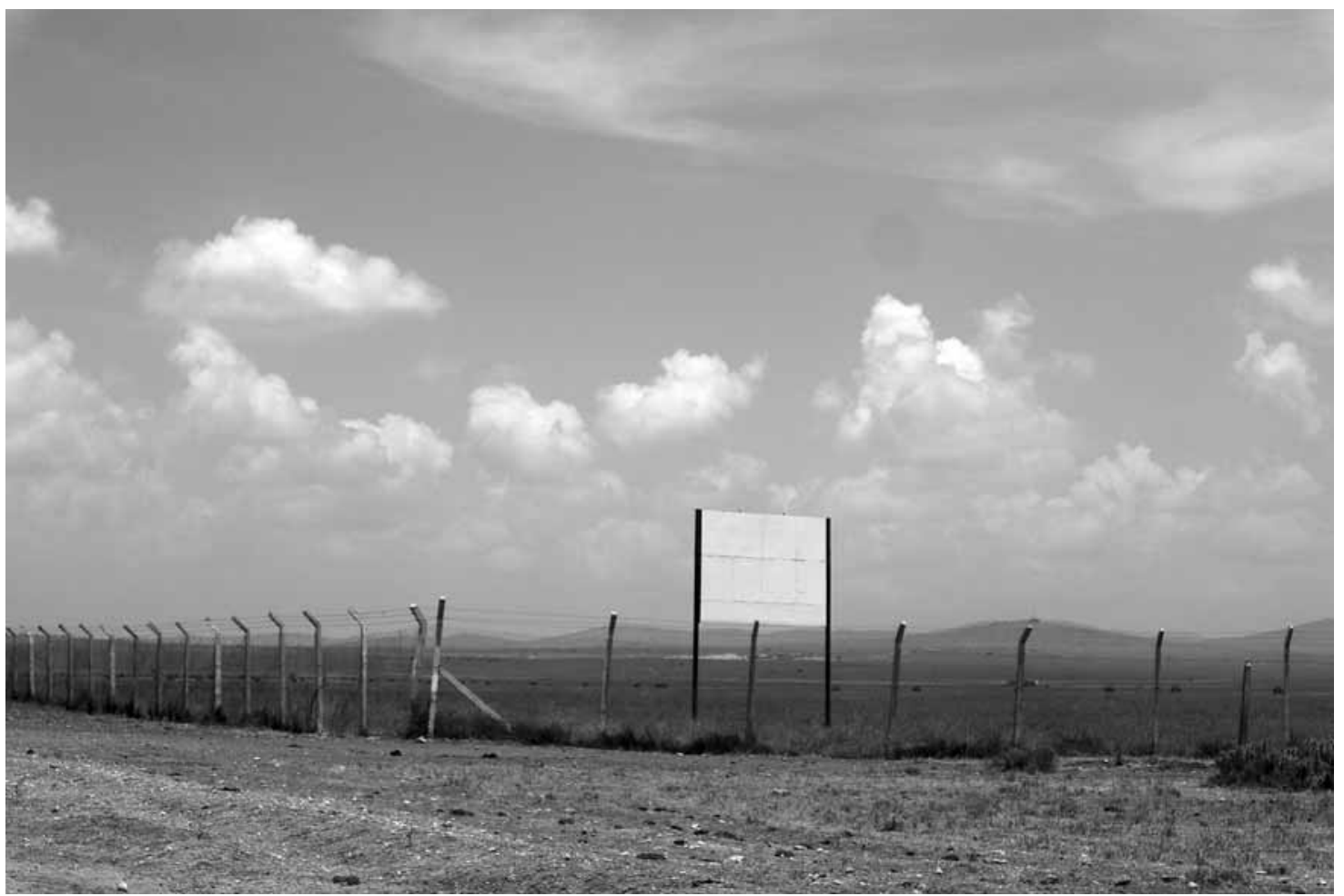

Figure 6. Fences surrounding the Konza Techno City project area. (Photo: D. Avianto) 
may risk indirect displacement, other groups may be attracted to the area exactly because of the Konza Techno City plans, as is the case in Malili. In tandem with population growth, high land speculation has been ongoing in Malili. Apart from people seeking employment, many also arrive seeking an increase in land prices and quick gains. Indeed, inhabitants and experts generally agreed that land prices have increased considerably since 2006-2007, and a number of group ranch shareholders has been able to earn a good profit. It thus shows that even if no real construction has yet happened, the mere existence of a project plan creates impacts. Villagers' views on rising land prices and speculation are mostly rather positive (interviews). While some benefit from opportunities, the majority of Malili settlers live in vulnerable circumstances (transect walks, interviews), and hopes for employment are hard to be fulfilled. Paradoxically, many of these recent settlers now face insecurity in their access to land and livelihoods: not only will their access to housing possibly be affected by the buffer zone regulation, they also face extra insecurities as a result of the chaotic local land market, with rapid land transfers and multiple claims on the same plot of land (Mwau, 2013). A potential new displacement chain is thus set in motion.

\section{Ambivalent Actors: State vs Communities}

In this section we analyse the multitude and ambivalence of actors around Konza Techno City. These issues are key to understanding land rights, as they affect the way the state deals with land acquisitions and with the buffer zone issue (including consultations with residents), and how people respond.

While Konza Techno City is backed by highlevel economic and political interests, the role of state institutions is contradictory and the state is far from monolithic. Through KoTDA, with the Ministry of Information and Communication (MIC) as the main government institute involved, the state acts as a land broker and provider of public infrastructure. As the project delays illustrate, this role is not a simple one: the state seems unable to steer process outcomes in such a complex project (van Noorloos et al., 2018). The reasons for the inability of the Kenyan state (so far) to develop the project, in spite of high-level support including the presidency, can be found in the fragmented nature of planning in Kenya and contradictory interests within the Kenyan state (Manji, 2015). While the MIC was deeply involved in advancing its vision for the project and committed to starting construction fast, its expertise is in ICT and not in urban planning or land development. This lack of expertise led to multiple changes in the project and failure to have public planning documents and environmental licensing documents submitted and approved (Splinter, 2014). The clash between ambitious objectives and institutional possibilities is also to blame: other important central government institutions such as the Ministry of Lands and Physical Planning and the National Environmental Management Authority were not sufficiently involved in Konza's high aspirations and plans from the start, and communication was ineffective (ibid.).

The state is thus an ambivalent actor in the development of new towns. This ambivalence is also clearly visible in the scalar developments and inter-county conflicts that emerged around Konza Techno City. The new city plans run through three different counties whose governments all claim the project in order to enhance their image and increase tax revenues. It is important for county governments to earn their own incomes, given Kenya's devolution of power as outlined in the 2010 Constitution. While metropolitan governance in a city-region would potentially be a solution in this case, the idea of metropolitan planning in Kenya (which was part of the Nairobi Metro 2030 plan) was abolished after devolution of power to counties became the new standard in 2010 (interview, former MIC policy-maker; Splinter, 2014). Despite devolution policy, in the face of new city 
plans such as Konza with its overarching Development Authority, the counties hardly have any real say in the developments, apart from being able to develop land-use plans (Interview, member of County Assembly of Makueni).

The planning of the buffer zone around the Konza project is a clear example of how fragmented governance and internal power struggles within the state have influenced local land rights. The first plan for a buffer zone, developed by the MIC, set out to prohibit any development in the buffer zone. However, the Ministry of Lands and Physical Planning in 2014 lifted the ban on development, providing a window for land owners to put up buildings within the framework of the Local Physical Development Plan as outlined above (Mark, 2014). Hence at least contradictory roles and interests within the government saved residents from having their villages completely removed. However, the manner in which the plan will be implemented and whether buildings will be demolished is still unclear for inhabitants (Konza Technopolis, 2017; interviews inhabitants), adding to their land tenure insecurity.

While the KoTDA and MIC were overridden a few times by the Ministry of Lands and Physical Planning, the general trend was that very high pressure was exerted by the MIC over other ministries to advance the project quickly and disregard procedures (Splinter, 2014). This was because of the strategic interest of Konza Techno City as a national status project within Kenya Vision 2030. From literature it appears that when political stakes are high and projects are developed with reference to the 'national interest', there is a large risk of fast-tracking procedures, which may heighten land tenure insecurity and thwart public participation in planning (Datta, 2015; Goldman, 2011; van Noorloos and Kloosterboer, 2018). These problems indeed materialized in Konza Techno City. Participation by and informed consultation with the inhabitants have hardly taken place. The speed of developments as soon as the green light was given probably left very little room for this. Both Konza and Malili dwellers mostly knew about the project through the mass media (e.g. a speech by the president on Konza on television), and only about half of them knew about buffer zone regulations (survey). A little more than a third of respondents was informed about the project through a baraza meeting (community meeting with the chief). The Development Authority has organized a number of such meetings leading up to the project (interview, chief Old Konza), which is a formality to fulfil planning regulations (the 2010 Constitution as well as Environmental Impact Assessment require public participation - Government of Kenya, 2016). However, according to the Old Konza chief, these meetings were characterized by one-way information flows, rather than actual participation. The degree of the citizen participation was only on the 'informing' level. Such participation is often dismissed as tokenism or symbolic (Arnstein, 1969).

The lack of adequate public participation does not mean inhabitants' perceptions of the project were necessarily negative: rather, communities were heterogeneous in their vision. Also, their opinions have changed over time, as there turned out to be a wide gap between people's high expectations and the very volatile and insecure nature of the new city. People's perceptions of the project generally started out positively, with high expectations of employment and business opportunities (e.g. shops) as well as urban services (interviews with inhabitants). For example, a 40-year-old woman, working as a shop-keeper, was expecting job opportunities for her daughter who had almost finished secondary school. Other people hoped to earn a good income from selling their land. There was also an ethnic element in the positive perception: Kamba are the main ethnic group in the area and bringing the project to 'their' land gave them pride and hope to boost their region as they feel 'left behind' by government. Interestingly, the Maasai minority was more 
critical, also because of the limitation of their grazing land mentioned before (interviews). In any case, as many respondents indicated, initial widespread positive perceptions of Konza Techno City in both villages have gradually made way for scepticism due to delays and political problems. It is important to note such changes over time in the actors' roles and interests, which take place even before any construction has started.

\section{Discussion and Conclusion}

This article has provided exploratory empirical evidence for African new cities' impacts on people's access to land and livelihoods. It has highlighted that new cities are inserted into real places with pre-existing activities, humans, and livelihoods which start to change and co-evolve as soon as an idea for a new city is elaborated. We have noted that the periurban spaces where many new cities are planned, are hardly ever empty, and insertion of new structures in such locations brings a risk of displacement, both physically and economically. In Konza Techno City the potential and real displacements were relatively small, given the low population density in the area, yet they still provide interesting insights into the process.

In the planning of Konza Techno City, a variety of land-related problems have emerged long before any real construction has started. The case illustrates well that the risk of displacement in the context of new cities includes more than just direct dispossession of land within the project area. Over time, different types of displacement chains can evolve (van Noorloos et al., 2018). Indirect displacement in this case took place by impeding the (partly) mobile livelihoods of pastoralists, and potentially by the establishment of a buffer zone with new land-use regulations around the new city - land tenure and livelihood insecurity for the future is the main issue there. At the same time, displacement chains that caused repulsion also ran parallel to processes of attraction of new inhabitants who were drawn by new aspirations and opportunities. These new inhabitants were not necessarily elites as is often assumed: in Malili, new vulnerable migrants coincide with land speculators and developers. Finally, the results of this study highlight the ambivalence of actors around new city projects (van Noorloos et al., 2018). Konza Techno City's powerful backing by high-level economic and political interests caused a lack of quality consultation and participation of surrounding inhabitants in the project planning. On the other hand, the fragmented and ambivalent character of the state caused huge delays, which caused further frustration among surrounding inhabitants, who were initially more welcoming of the project (though their views were also heterogeneous).

Indeed, this peri-urban case of land investment shows us that it is not easy to draw the line between 'grab' and 'development' or assign clear 'culprits': spatial differences and temporal changes make for a constantly shifting landscape of actual and potential impacts. While the often-studied policy framings and realities, the planning models, and the financial flows of new cities are important in understanding how and why new cities are re-emerging in Africa (Carmody and Owusu, 2016; Cirolia, 2014; Côté-Roy and Moser, 2018; Fält, this issue; Grant, 2015; van Noorloos and Kloosterboer, 2018; Watson, 2013), the local impacts of these projects deserve more attention in themselves. As the rural land grab literature has shown, local impacts, views and responses to land deals are multiple and complex and differ according to space and time (Sassen, 2014; Zoomers, 2010; Zoomers et al., 2017): they are in themselves highly influenced by global processes. When the investment is peri-urban, these issues are only intensified, and intermingled with preexisting urban transformations, aspirations and livelihoods.

The main problem of new cities lies in the failure to accept 'informal' development as being an intrinsic part of African cities (Parnell and Pieterse, 2014). This problem is 
well-known: new cities are often planned as gated middle-class or higher-class enclaves disconnected from the real cities. What this case of Konza Techno City also shows is that the negation of informality also clearly presents itself in the planning of new cities' surroundings, and thereby impacts the daily lives and prospects of pre-existing and surrounding residents, by making access to land and livelihood less secure. On the other hand, the fragmentation of governance and the consequent delays and failure to act, have only increased informal and speculative land developments around Konza Techno City and made it all the more difficult to reach a utopian 'well-planned' vision for the country.

\section{NOTES}

1. For an explanation and discussion of how the originally rural concept of 'land grab' can be useful for analysing developments in cities, see the introduction to this special issue, as well as the work by Zoomers et al. (2017) and Steel et al. (2017).

2. The third line of thought is less relevant here, as it focuses more specifically on the vertical dimensions of inner-city investments.

3. The master plan for phase I is prepared by a consortium of ten international development companies, among which are global, US-based, Germany-based, and Kenya-based consultants, architects, and real estate advisors, and the IT firm Cisco based in San Jose, CA, USA (Klaufus et al., 2017).

4. A group ranch can be defined as 'a livestock production system or enterprise where a group of people jointly own freehold title to land, maintain agreed stocking levels and herd their livestock collectively which they own individually' (Ministry of Agriculture, 1968, in Ng'ethe, 2009).

\section{REFERENCES}

Arnstein, S.R. (1969) A ladder of citizen participation. Journal of the American Planning Association, 35(4), pp. 216-224.

Avianto, D. (2017) Konza Techno City and Its Impact on Surrounding Local Communities. Masters Thesis, University of Utrecht.
Bunnell, T. (2015) Antecedent cities and interreferencing effects: learning from and extending beyond critiques of neoliberalisation. Urban Studies, 52(11), pp. 1983-2000.

Cain, A. (2014) African urban fantasies: past lessons and emerging realities. Environment and Urbanization, 26(2), pp. 561-567.

Carmody, P. and Owusu, F.Y. (2016). Neoliberalism, urbanization and change in Africa: the political economy of heterotopias. Journal of African Development, 18, pp. 61-73.

Cirolia, L.R. (2014) Escaping the challenges of the city: a critique of Cape Town's proposed satellite town. Urban Forum, 25, pp. 295-312.

Côté-Roy, L. and Moser, S. (2018) ‘Does Africa not deserve shiny new cities?' The power of seductive rhetoric around new cities in Africa. Urban Studies. e-pub ahead of print, https://doi.org/10.1177/ 0042098018793032.

Croese, S. and Pitcher, M.A. (2019) Ordering power? The politics of state-led housing delivery under authoritarianism - the case of Luanda, Angola. Urban Studies, 56(2), pp. 401-418.

Datta, A. (2015) New urban utopias of postcolonial India: 'entrepreneurial urbanization' in Dholera smart city, Gujarat. Dialogues in Human Geography, 5(1), pp. 3-22.

De Boeck, F. (2011) Inhabiting ocular ground: Kinshasa's future in the light of Congo's spectral urban politics. Cultural Anthropology, 26(2), pp. 263-286.

Dell'Angelo, J., D'Odorico, P., Rulli, M.C. and Marchand, P. (2017) The tragedy of the grabbed commons: coercion and dispossession in the global land rush. World Development, 92, pp. 1-12.

DPP (Director of Physical Planning) (2013) Konza Local Physical Development Plan - (2012-2030). Nairobi: Ministry of Lands.

Gillespie, T. (2016) Accumulation by urban dispossession: struggles over urban space in Accra, Ghana. Transactions of the Institute of British Geographers, 41(1), pp. 66-77.

Goldman, M. (2011) Speculative urbanism and the making of the next world city. International Journal of Urban and Regional Research, 35(3), pp. 555-581.

Government of Kenya (2007) Kenya Vision 2030: The Popular Version. Available at: http://vision2030. go.ke/inc/uploads/2018/05/Vision-2030-PopularVersion.pdf.

Government of Kenya (2016) County Public Participation Guidelines. Nairobi: Ministry of Devolution and Planning and Council of Governors. 
Government of Kenya (2018). Kenya Vision 2030: Sector Progress and Project Updates. June 2018. Available at: http://vision2030.go.ke/publication/ kenya-vision-2030-sector-progress-project-up dates-june-2018/.

Grant, R. (2015) Sustainable African urban futures. Stocktaking and critical reflection on proposed urban projects. American Behavioral Scientist, 59(3), pp. 294-310.

IFC (International Finance Corporation), World Bank (2014) Public-Private Partnership Stories Kenya: Konza Technology City (KMIP). Washington DC: IFC. Available at: http://documents. worldbank.org/curated/en/5638614680 01776522/pdf/96904-BRI-PUBLIC-PPPStoriesKenya-KonzaTechnologyCity-KMIP.pdf.

Johari, A. (2015) Kenya's Konza Techno City: Utopian Vision Meets Social Reality. Independent Study Project (ISP) Collection, Paper 2024.

Keeton, R. and Provoost, M. (eds.) (forthcoming) Urban Africa - A Handbook for New Planned Cities. Rotterdam: nai010 Publishers.

Klaufus, C., van Lindert, P., van Noorloos, F. and Steel, G. (2017) All-inclusiveness versus exclusion: urban project development in Latin America and Africa. Sustainability, 9, 2038. doi:10.3390/su9112038.

Konza Technopolis (2015) Abridged Strategic Plan 2020. Nairobi: Konza Technopolis. Available at: http://www.konzacity.go.ke/wp-content/ uploads/2014/12/KoTDAs-Strategic-Plan-2020Abridged-Version.pdf.

Konza Technopolis (2017) Frequently Asked Questions (FAQs) about Konza Technopolis. Nairobi: Konza Technopolis. November 2017. Available at: http://www.konzacity.go.ke/wpcontent/uploads/2014/12/Frequently-AskedQuestions-about-Konza-Technopolis-Nov ember-20171.pdf.

Leitner, H. and Sheppard, E. (2018) From kampungs to condos? Contested accumulations through displacement in Jakarta. Environment and Planning A, 50(2), pp. 437-456.

McCann, E. (2011) Urban policy mobilities and global circuits of knowledge: toward a research agenda. Annals of the Association of American Geographers, 101(1), pp. 107-130.

McCann, E. (2013) Policy boosterism, policy mobilities, and the extrospective city. Urban Geography, 34(1), pp. 5-29.

McCann, E. and Ward, K. (2012) Policy assemblages, mobilities and mutations: toward a multidisciplinary conversation. Political Studies Review, 10(3), pp. 325-332.
Manji, A. (2015) Bulldozers, homes and highways: Nairobi and the right to the city. Review of African Political Economy, 42(1), pp. 1-19.

Mark, O. (2014) State lifts ban on Konza buffer land use. Business Daily. Available at: http:// www.businessdailyafrica.com/State-lifts-banon-Konza-buffer-land-use-/-/539546/2232384//3jgtcf/-/index.html.

Mulinge, M. (2014) Emerging Human Settlement Patterns around the Planned Konza City: A Case of Malili Centre. Bachelor Thesis, University of Nairobi.

Murray, M.J. (2015) Waterfall City (Johannesburg): privatized urbanism in extremis. Environment $\mathcal{E}$ Planning A, 47(3), pp. 503-520.

Mwangi, E. (2007) The puzzle of group ranch subdivision in Kenya's Maasailand. Development and Change, 38(5), pp. 889-910.

Mwau, B. (2013) The planned hatches the unplanned. Living the City: Urban Africa. Available at: https://slumurbanism.wordpress.com/2013/ 08/02/the-planned-hatches-the-unplanned/.

Ng'ethe, J. (2009) Group Ranch Concept and Practice in Kenya with Special Emphasis on Kajiado District. Rome: FAO. Available at: http://www.fao.org/ Wairdocs/ILRI/x5485E/x5485e0t.htm.

Parnell, S. and Pieterse, E. (eds.) (2014) Africa's Urban Revolution. London: Zed Books.

Planel, S. and Bridonneau, M. (2017) (Re)making politics in a new urban Ethiopia: an empirical reading of the right to the city in Addis Ababa's condominiums. Journal of Eastern African Studies, 11(1), pp. 24-45.

Roy, A. and Ong, A. (eds.) (2011) Worlding Cities: Asian Experiments and the Art of Being Global. Oxford: Wiley-Blackwell.

Sassen, S. (2014) Expulsions. Brutality and Complexity in the Global Economy. Cambridge, MA: Harvard University Press.

Scott, J.C. (1998) Seeing Like a State: How Certain Schemes to Improve the Human Condition Have Failed. New Haven, CT: Yale University Press.

Sheppard, E., Gidwani, V., Goldman, M. et al. (2015) Introduction: urban revolutions in the age of global urbanism. Urban Studies, 52(11), pp. 1947-1961.

Smith, C. (2017) 'Our changes'? Visions of the future in Nairobi. Urban Planning, 2, pp. 31-40.

Splinter, E. (2014) Between Vision and Reality: The Troublesome Implementation of Neoliberal Projects. MSc Thesis University of Amsterdam.

Steel, G., van Noorloos, F. and Klaufus, C. (2017) 
The urban land debate in the global south: new avenues for research. Geoforum, 83, pp. 133-141.

The Star (2018) Kenya struggles to actualise Konza 'Silicon Savannah' city. The Star, 11 December. Available at: https://www.the-star.co.ke/ news/2018/12/11/kenya-struggles-to-actualisekonza-silicon-savannah-city_c1864178.

van Noorloos, F. and Kloosterboer, M. (2018) Africa's new cities: the contested future of urbanisation. Urban Studies, 55(6), pp. 12231241.

van Noorloos, F., Klaufus, C. and Steel, G. (2018) Critical commentary: land in urban debates: unpacking the grab-development dichotomy. Urban Studies, e-pub ahead of print, doi 10.1177/0042098018789019.

van Noorloos, F. and Avianto, D. (forthcoming) New Towns, Old Places. Four Lessons from Konza Techno City, in Keeton, R. and Provoost, M. (eds.) Urban Africa - A Handbook for New Planned Cities. Rotterdam: nai010 Publishers.
Wapenaar, M. (2015) Formal Planning \& Informal Settlement. The Case of Konza Technology City. MSc thesis, Universiteit van Amsterdam.

Watson, V. (2013) African urban fantasies: dreams or nightmares? Environment and Urbanization, 26(1), pp. 215-231.

Zoomers, A. (2010) Globalization and the foreignization of space: the seven processes driving the current global land grab. Journal of Peasant Studies, 37(2), pp. 429-447.

Zoomers, A., van Noorloos, F., Otsuki, K., Steel, G. and van Westen, G. (2017) The rush for land in an urbanizing world - from land grabbing towards developing safe, resilient and sustainable cities and landscapes. World Development, 92, pp. 242-252. 